\title{
The Effect of Halal Tourism on Customer Satisfaction
}

\author{
Muhammad Sindhu Danu Saputro ${ }^{1}$ Yunia Wardi² Abror Abror ${ }^{3}$ \\ ${ }^{1}$ Faculty of Economics, Universitas Negeri Padang, Padang, Indonesia \\ $\bowtie$ (e-mail) msindhuds@yahoo.com \\ ${ }^{2}$ Dept. of Management, Faculty of Economics, Universitas Negeri Padang, Padang, Indonesia \\ $\triangle$ (e-mail) yuniawardi@fe.unp.ac.id \\ ${ }^{3}$ Dept. of Management, Faculty of Economics, Universitas Negeri Padang, Padang, Indonesia \\ $\triangle$ (e-mail) abror094@fe.unp.ac.id
}

\begin{abstract}
This study analyzes the influence of Halal tourism dimensions (i.e., Islamic facilities, Halal, Islamic culture, and free from alcohol drinks and gambling) on tourist satisfaction in West Sumatra. This research is a causative research which examines the influence of Islamic facilities, Halal, Islamic culture, free from of alcohol drinks and gambling on tourist satisfaction. The respondents of this study were domestic and foreign tourists who have visited West Sumatra. This study employed a purposive sampling technique for the data collection. The multiple linear regressions had been conducted to analyze the data. The results show that all of the Halal tourism dimensions, including Islamic facilities, Halal, Islamic culture, and free from of alcoholic beverages and gambling have a positive and significant impact on the satisfaction of tourists in West Sumatra. Some limitations and future studies are discussed.

Keywords: Islamic facilities, halal, Islamic culture, tourist satisfaction, free from alcohol drinks and tourist gambling
\end{abstract}

\section{Introduction}

Halal tourism has spread widely and become popular in recent decades, occupying an important segment of international tourism and has grown substantially in recent years. Halal tourism became one of the less-studied topics in the tourism research area (Timothy \& Olsen, 2006: 1). Consistent growth in this market segment has become a global trend in the tourism industry. Religiosity based travel is not regarded as a new phenomenon for a Halal tourism, it has become an integrated motive and it is usually considered the oldest form of economic travel. Religion has played an important role in tourism development over the centuries and has influenced how people make use of leisure time. Timothy \& Olsen (2006: 9) explain that the increasing number of tourists with religious motivation has also attracted the attention of academics, government and tourism agencies to develop tourism. The study shows that the main purpose for a large number of religious tourists is related to the visit. Halal tourism became one of the trends in the world market. Starting from Halal facilities, Halal food, Islamic Culture, free from alcoholic beverages and gambling to lodging Halal much put forward by various countries Battour and Ismail (2014).

Halal destinations are now widely encountered in various non-Muslim countries around the world. For example, Thailand issued a special application for Muslim tourists to make their country friendlier to Muslim tourists (Afif, 2015). In particular, Halal tourism is a trade or business activity (Halal tourism). In Islamic literature, the term "Halal" refers to all that is commanded in the teachings of religion and becomes the basis for the behavior and activities of Muslims. Halal tourism itself is part of the tourism industry devoted to Muslim tourists, in this case the service of tourists refers to the rules of Islam.

The Province of West Sumatera has just been awarded four categories, namely Best Halal Travel Destination, Best Culinary Destinations, Best Halal Restaurants, and the Best Halal Travel Bureau at the national level. And then West Sumatra will also represent Indonesia in the event of World Halal Tourism Award 2016 in Abu Dhabi, United Arab Emirates (UAE). The concept of Halal tourism 
applied in West Sumatra is considered to attract investors to invest in the area so that tourists who visit increases. Proven by the number of foreign tourists visiting West Sumatra based on the Central Statistics Agency of West Sumatra Province reached 48. 722 people in 2017, This makes West Sumatra increasingly improve itself in improving the quality of Halal tourism in the eyes of domestic and international tourists.

Broadly speaking, Halal tourism is Halal tourism that must be fulfilled the terms of conditions to be said worthy as a destination for Muslim tourists both domestic and foreign, According to Battour and Ismail (2014) there are 4 factors that determine a decent tourist area to be the destination of Muslim tourists, namely Islamic Facilities, Halal, Islamic Culture, the absence of alcohol and gambling. Kotler (2009: 139) states that satisfaction is the feeling of pleasure or disappointment of someone who arises because it compares perceived performance to the product on customer expectations. According to Battour (2014) satisfaction of tourists can be influenced by Halal tourism factors consisting of Halal, Islamic culture, the absence of alcohol consumption and gambling practices.

According to research conducted Rahmatya (2010) Satisfaction is a state where the wishes, expectations and customer needs are met. Engel (1995) describes customer satisfaction as a full-time evaluation in which the chosen alternative is at least equal or exceeds the customer's expectation, while dissatisfaction arises when results do not meet customer expectations. According to Kotler (2008) satisfaction is the level of one's satisfaction after comparing performance or perceived results compared with expectations. The concepts that can be used for measuring customer satisfaction are overall customer satisfaction, customer satisfaction dimension, confirmation of expectations, interest re-visit, willingness to recommend, customer dissatisfaction (Umar, 2003). If the customer is comfortable with what he gets, then the customer is likely to feel satisfied.

There is a lot of understanding given by the writers about Halal Tourism, such as Rosyidi (2015) and Wardi, Abror and Trinanda (2018) who stated that Halal tourism is part of the tourism industry devoted to Muslim tourists. According to Battour and Ismail (2014) Halal tourism is a tourist activity with a thick Islamic atmosphere both the city of destination culture, the tourists themselves and the activities and facilities that exist. There are some factors which support in Islamic Tourism namely: Good Islamic facilities Food, hotels and mosques, halal includes food, tourist sites and hotels. Islamic Culture tourist destination city and the Government or the organizer itself to place the tourist town as a destination Islamic Tourism. Halal Tourism has several indicators in it to go to the Customer Satisfaction or Islamic Tourist, so the Indicator used in this research is taken from the research of Battour and Ismail (2014) which include: Islamic Facilities, Halal, Islamic Culture and free from alcoholic beverages and Gambling.

Battour and Ismail (2014) argue that the Islamic community has special treatment and a special purpose, in his research argued that Islamic facilities have an effect on satisfaction. Gusneli, (2016). Arguing that Overall assessment given visitors to tourism facilities and visitor satisfaction to the object of Sani Bayang positive waterfall, based on the results of research conducted, indicating that the tourism facilities affect visitor satisfaction. Based on the description of the phenomenon and the background of the problem mentioned above, then the researcher is interested to do research back to a number of variables that can influence and strengthen the satisfaction of tourists.

\section{Methods}

The population of this research is the tourists who visit West Sumatra. This study employed the questionnaire to collect the data. This study collected the data from 400 respondents as follows in the table 1 
Table 1 Sample of halal tourism research of West Sumatra

\begin{tabular}{clccc}
\hline No & \multicolumn{1}{c}{ City } & $\begin{array}{c}\text { Number of Tourist } \\
\text { Attraction* }\end{array}$ & $\begin{array}{c}\text { Proportional } \\
\text { Sampling }\end{array}$ & Sample \\
\hline 1 & Padang & 44 & 149.15 & 150 \\
\hline 2 & Bukittinggi & 31 & 105.08 & 106 \\
\hline 3 & Payakumbuh & 16 & 54.24 & 55 \\
\hline 4 & Batusangkar & 10 & 33.90 & 34 \\
\hline 5 & Pesisir Selatan & 17 & 57.63 & 58 \\
\hline & TOTAL & 118 & 400 & 403 \\
\hline
\end{tabular}

To know the effect of independent variable to dependent variable. Then used multiple linear regression test. Hypothesis test in this research use $t$ test.

\section{Results and Discussion}

The of multiple linear regression on the effect of Halal tourism on tourist satisfaction as shown in the Table 2 below.

Table 2 Results of Multiple Linear Regression

\begin{tabular}{lccc}
\hline \multicolumn{1}{c}{ Research variable } & Coefficient & t-value & Sig \\
\hline (Constant) & 1.242 & - & - \\
\hline Islamic facilities $\left(\mathrm{X}_{1}\right)$ & 0.243 & 4.469 & 0.000 \\
\hline Halal $\left(\mathrm{X}_{2}\right)$ & 0.191 & 3.803 & 0.000 \\
\hline Islamic Culture $\left(\mathrm{X}_{3}\right)$ & 0.043 & 0.708 & 0.479 \\
\hline Free from Alcoholic Beverages and gambling $\left(\mathrm{X}_{4}\right)$ & 0.258 & 5.684 & 0.000 \\
\hline$\quad$ Source: Processed Data, 2018 & & &
\end{tabular}

Table 1 shows the coefficient and the significant level of each research variable. Moreover, the equation below shows the regression coefficients for the variables:

$\mathrm{Y}=1.242+0.243 \mathrm{X}_{1}+0.191 \mathrm{X}_{2}+0.043 \mathrm{X}_{3}+0.258 \mathrm{X}_{4}$

The value of the constant generated in the test is 1.242 . The value of the resulting constant coefficient indicates when it is assumed that there is no change of Islamic Facilities $\left(X_{1}\right)$. Halal $\left(X_{2}\right)$, Islamic Culture $\left(X_{3}\right)$, and Free of Alcoholic Beverages and gambling $\left(X_{4}\right)$, satisfaction $\left(X_{5}\right)$ is the constant value of 1.242. The value of the obtained constant coefficients also implies without the five independent variables used in the satisfaction regression model.

Variable of Islamic Facilities $\left(X_{1}\right)$ has positive regression coefficient of 0.243 resulted coefficient value when assumed increase of Islamic Facilities $\left(X_{1}\right)$ equal to 1 unit in each tourist will encourage increase of satisfaction ( $\mathrm{X}_{5}$ ) equal to 0.243 with assumption other factor besides Islamic Facility is considered constant or constant and vice versa.

Then the variable of Halal $\left(\mathrm{X}_{2}\right)$ has a positive signified regression coefficient of 0.191 . The result obtained shows that it is assumed that an increase of Halal $\left(X_{2}\right)$ in each tourist by 1 unit will encourage the increase of satisfaction $\left(X_{5}\right)$ of 0.191 with the assumption that other factors besides Halal (X2) are considered constant or constant.

In the equation model looks Islamic Culture variables $\left(X_{3}\right)$ has positive signified regression coefficient of 0.043 . The results obtained show that when it is assumed that the increase of Islamic Culture $\left(X_{3}\right)$ value in tourist will encourage the strengthening of satisfaction $\left(X_{5}\right)$ of 0.043 units with the assumption that other factors besides the Islamic Culture are considered constant or constant.

In the model, the independent variables of free from alcoholic beverages and gambling $\left(\mathrm{X}_{4}\right)$ have positive regression coefficient of 0.258 . The results obtained show that when it is assumed that an increase in the value of free alcoholic beverages and gambling $\left(\mathrm{X}_{4}\right)$ in tourists will encourage the 
strengthening of satisfaction $\left(\mathrm{X}_{5}\right)$ of 0.258 units with the assumption that factors other than the alcohol-free and gambling-free are constant. In the regression analysis model, independent variables of free from alcoholic beverages and gambling have the highest regression coefficients, so it can be concluded that Free from Alcoholic Beverages and gambling is the independent variable with the highest contribution to influence satisfaction.

\section{The influence of Halal tourism to the satisfaction of tourists in West Sumatra}

The first hypothesis to the fourth to test the effect of Halal tourism to the satisfaction of tourists in West Sumatra Based on the results of tests that have been done obtained a summary seen in the Table below:

Table 3 Results of hypotheses testing

\begin{tabular}{llll}
\hline Research variable & Sig & Alpha & Conclusion \\
\hline Islamic Facilities $\left(\mathrm{X}_{1}\right)$ & 0.000 & 0.05 & Significant \\
\hline Halal $\left(\mathrm{X}_{2}\right)$ & 0.000 & 0.05 & Significant \\
\hline Islamic culture $\left(\mathrm{X}_{3}\right)$ & 0.479 & 0.05 & Not significant \\
\hline Free from alcoholic beverages and gambling $\left(\mathrm{X}_{4}\right)$ & 0.000 & 0.05 & Significant \\
\hline $\mathrm{R}^{2}=0.361$ & & & \\
\hline F-sig $=47.983$ (sig. $0.000<0.05)$ & & & \\
\hline$\quad$ Source: Processed Data, 2018 & &
\end{tabular}

The first hypothesis shows the influence of Islamic Facilities $\left(\mathrm{X}_{1}\right)$ on Satisfaction $(\mathrm{Y})$. We found that the Islamic facilities have a significant impact on satisfaction with the significant value of 0.000 . The data processing is done by using the error rate of 0.05 . The results obtained show that the sig value of 0.000 <alpha 0.05 then the decision is $\mathrm{H}_{0}$ rejected and $\mathrm{H}_{1}$ accepted so it can be concluded Islamic Facilities $\left(X_{1}\right)$ have a significant effect on Satisfaction $(X 5)$. The second hypothesis that aims to obtain empirical evidence of the influence of Halal $\left(\mathrm{X}_{2}\right)$ on Satisfaction $(\mathrm{Y})$ obtained sig value of 0.000 . The data processing is done by using the error rate of 0.05 . Results obtained show that the sig value of 0.000 <alpha 0.05 then the decision is Ho rejected and $\mathrm{H}_{2}$ accepted so it can be concluded Halal $\left(\mathrm{X}_{2}\right)$ have a significant effect on Satisfaction $(\mathrm{Y})$.

The third hypothesis by using Islamic Culture variables $\left(X_{3}\right)$ obtained sig value of 0.479 . The data processing is done by using the error rate of 0.05 . The results obtained show that the sig value of 0 . $479>$ alpha 0.05 then the decision is Ho accepted and $\mathrm{H}_{3}$ is rejected so it can be concluded that Islamic Culture $\left(X_{3}\right)$ has no significant effect on Satisfaction $\left(X_{5}\right)$. The fourth hypothesis that aims to obtain empirical evidence of the influence of free from alcoholic beverages and gambling $\left(\mathrm{X}_{4}\right)$ to Satisfaction (Y) obtained sig value of 0.000 . The data processing is done by using the error rate of 0.05 . The results obtained show that the sig value of $0.000<$ alpha 0.05 then the decision is Ho is rejected and $\mathrm{H}_{4}$ accepted so it can be concluded Free from alcoholic beverage and gambling $\left(\mathrm{X}_{4}\right)$ have a significant effect on Satisfaction $\left(\mathrm{X}_{5}\right)$.

\section{The Influence of Islamic Facilities on Tourist Satisfaction in West Sumatra}

From the results of the first hypothesis testing is known that there is a significant influence of Islamic facilities on the satisfaction of tourists in West Sumatra. Islamic facilities variables significantly influence the satisfaction of tourists means that the findings show that Islamic facilities contribute to the satisfaction of tourists. Thus it can be said that with the availability of the mosque in sufficient quantities, the facilities of worship at the tourist sites are available in sufficient quantities, the Adzan can be heard easily when the time of prayer entered, the Hotel has provided prayer rugs, the hotel has provided Quran in every room, has been available adequately on toilets, malls and hotels/lodgings, and the squat closet is readily available on toilets, malls and hotels/inns will make tourists satisfied with the tourist attractions of West Sumatra. 
Signs of positive regression coefficient of Islamic facilities variable indicate that there is a direct relationship of variable Islamic facilities with variable satisfaction of tourists, if the better and the availability of Islam facilities then the higher the satisfaction of tourists in tourist attractions in West Sumatra. Based on the findings of this research can be said that the satisfaction of tourists in tourist attractions in West Sumatra is determined by Islamic facilities such as the availability of a mosque in sufficient quantities, facilities of worship at tourist sites have been available in sufficient quantities, Adzan can be heard easily when the time of praying entrance, has provided a prayer rug, the hotel has provided the Quran in every room, clean water is readily available on toilets, malls and hotels/lodgings, and squat closet is available adequately on toilets, malls and hotels/inns will make tourists satisfied on the tourist attractions in West Sumatra.

The findings of this study are supported by the result of analysis of variable description of Islamic facilities which shows that Islamic facilities are in enough category. This is certainly a factor that affects the tourist satisfaction because with the better Islamic facilities will be more satisfied tourists. The availability of Islamic facilities in sufficient quantities will increase the satisfaction of tourists. The result of this study is in line with Ki Lee (2008) who argue that the facilities' quality has a significant impact on the customer satisfaction. Furthermore, Nash (2006) also asserts that the good facilities' condition is one of the determinant factors for visitor satisfaction. Odeny (2013) has also shown that the facility is one of the factors that support satisfaction. More specifically, the results of Zailani's (2016) study show that the availability of worship facilities is one of the factors of practice that can affect satisfaction. While the results of research Cronin (2000) showed that the facility is one indicator on satisfaction.

\section{Influence Halal on Tourist Satisfaction in West Sumatra}

Based on the results of the second hypothesis testing it is known that Halal has a significant effect on Tourist Satisfaction in West Sumatra. This shows that the more Halal tourist attractions in West Sumatra will increase the satisfaction of tourists. This means that the findings indicate that Halal contributes to the satisfaction of tourists. Thus, it can be said that the increasing availability of Halal food is available at tourist sites, malls, hotels, etc. Hotels / inns and restaurants have provided Halal kitchens, tourist sites have provided special places for women (such as beaches, SPA places etc.), and Hotels / the inn has protected the TV channel from broadcasts smelling pornography then it will make the tourists become satisfied at the tourist attractions in West Sumatra

The sign of positive regression coefficient of Halal variable shows that there is a direct relationship of Halal variable with variable of tourist satisfaction, if the increasing of Halal at tourist object in West Sumatera hence the higher also the satisfaction of tourists at tourist place in West Sumatera. Based on the findings of this research can be said that the satisfaction of tourists in tourist attractions in West Sumatra is determined by Halal as the availability of Halal food is available at tourist sites, malls, hotels, etc., Hotels / inns and restaurants have provided Halal kitchens, tourist sites have provided a special place for women (such as beaches, SPA places etc.), and hotels / inns have protected the TV channels from broadcasting smelling pornography then it will make tourists become satisfied at the tourist attractions in West Sumatra.

The findings of this study are supported by the results of the analysis of Halal variable that shows that Halal is in the category enough. This is certainly a factor that affects the satisfaction of tourists because with increasing Halal will be more satisfied tourists. The results of this study are in line with the results of Eid's study (2013) which shows that Halal seen from the availability of Halal food, the availability of separate facilities between men and women, and the availability of kosher entertainment affect the satisfaction of tourists. Battour research results (2010) showed that the availability of Halal food is one factor that makes tourists visit and satisfied at tourist attractions in Malaysia. In line with the results of Halim's research (2015) which shows that Halal food is one of the factors considered by tourists. 


\section{The Influence of Islamic Culture on Tourist Satisfaction in West Sumatra}

Based on the results of testing the third hypothesis is known that the Islamic Culture has no significant effect on Tourist Satisfaction in West Sumatra. This means that the high level of tourists in tourist attractions in West Sumatra is not influenced by Islamic Culture. The findings of this study prove that the satisfaction of tourists is not influenced by Islamic culture. This proves that the Islamic culture seen from hotel / lodging and restaurant employees has used Islamic dress, many people who wear Islamic dress (example of hijab) in public places, the Government has banned the practice of prostitution, the Government has banned sex activities in public areas (example, kissing etc.), and the Government has banned the adult scene on TV is not a factor causing the emergence of tourist satisfaction. That is, the satisfaction of tourists is not determined by Islamic culture.

The results of this study are not in line with the results of research Battour (2010) which shows that Islamic culture such as the call to prayer or prayer time, no sexual activity in public, and Islamic burial are some factors that make tourists visit and satisfied at tourist attractions in Malaysia. Furthermore, the results of research Wirandanan (2017) argued that Islamic culture shows a positive influence on satisfaction. Then the research results Kamarudin (2012) states that the life style of Islamic and Islamic activities is one of the factors that determine satisfaction.

\section{Free Effect of Alcoholic Beverages and Gambling on Tourists Satisfaction in West Sumatra}

From the results of the fourth hypothesis testing it is known that there is a significant influence of free of alcoholic beverages and gambling on the satisfaction of tourists in West Sumatra. The independent variables of alcoholic beverages and gambling have a significant effect on the satisfaction of tourists means that the findings indicate that the independent variables of alcoholic beverages and gambling contribute to the satisfaction of tourists. Thus, it can be said that with the prohibition of Government on the distribution of alcoholic beverages in the public area and the prohibition of Government on gambling practices in public areas will make tourists become satisfied at tourist attractions in West Sumatra.

Signs of positive regression coefficient of independent variables of alcoholic beverages and gambling show that there is a direct relationship of independent variables of alcoholic beverages and gambling with variable satisfaction of tourists, if the prohibition on alcoholic beverages and gambling then the higher the satisfaction of tourists at tourist attractions in West Sumatra. Based on the findings of this study can be said that the satisfaction of tourists in tourist attractions in West Sumatra is determined by the prohibition of alcoholic beverages and gambling as the Government has prohibited the distribution of alcoholic beverages in the public area and the Government has banned gambling practices in public areas will make tourists become satisfied on tourist attractions in West Sumatra.

The findings of this study are supported by the results of the analysis of the description of the independent variables of alcoholic beverages and gambling which show that free of alcoholic beverages and gambling are in good category. This is certainly a factor that affects the satisfaction of tourists because with the prohibition on alcoholic beverages and gambling will be more satisfied tourists. The results of this study are in line with the results of research Battour and Ismail (2014) which shows that satisfaction is influenced by free of alcoholic beverages and gambling. Further research results Wan Ko (2002) showed that the absence of alcohol, prostitution, gambling, criminal, and exploitation is an indicator of the positive impact felt by tourists who affect the satisfaction.

\section{Conclusions}

Based on the results of data analysis and discussion, we may conclude that: (1) Islamic facilities have a positive and significant impact on Tourist Satisfaction in West Sumatra. The better the available Islamic facilities will be able to increase the satisfaction of tourists in West Sumatra; (2) Halal has positive and significant impact on Tourist Satisfaction in West Sumatera. The better the Halal it will be able to increase the satisfaction of tourists in West Sumatra; (3) Islamic culture does not have a 
positive and significant impact on tourist satisfaction in West Sumatra. This means that the high level of customer satisfaction is not influenced by Islamic culture; (4) Free from Alcoholic Beverages and Free gambling have a positive and significant impact on Tourists Satisfaction in West Sumatera. The ban on alcoholic beverages and gambling will be able to increase the satisfaction of tourists in West Sumatra.

In an effort to increase the satisfaction of Tourists in West Sumatra, it can be done the following efforts: (1) In order to enhance the satisfaction of travelers it is necessary to take action relating to free of alcoholic beverages and gambling such as the existence of government actions in banning alcoholic beverages in public areas and prohibiting the practice of gambling in public areas; (2) In order to increase the satisfaction of tourists need to take actions related to Islamic facilities such as Provide Quran in every hotel room, Increase the number of closed squat on the toilets of tourist attractions, malls and hotels / inns, Provide a row in every hotel room, availability of clean water on toilets, malls and hotels / inns, Increasing number of worship facilities at tourist sites, and availability of mosques with sufficient quantities; (3) In order to increase the satisfaction of tourists need to take action relating to Halal such as Provide a special place for women (such as beaches, SPA places etc.), Improving the protection of TV channels from pornographic broadcasts on every hotel and inn, Providing Halal kitchen at every hotel and lodging, Halal food is always available at tourist sites, malls, hotels, etc.

\section{References}

Arif. (2015). Pengantar Ilmu Perhotelan dan Restoran. Yogyakarta: Graha Ilmu.

Battour, Mohamed. (2010). The impact of destination attributes on Muslim tourist's choice. International Journal of Tourism Research Int. J. Tourism Res.

Battour, M., \& Ismail, M. N. (2014). The role of destination attributes in Islamic tourism. SHS Web of Conferences, 12, 01077.

Battour, M., Battor, M., \& Bhatti, M. A. (2014). Islamic Attributes of destination: Construct development and measurement validation, and their impact on tourist satisfaction. International Journal of Tourism Research, 16(6), 556-564. doi: 10.1002/jtr.1947.

Cronin, Joseph. (2000). Assessing the effects of quality, value, and customer satisfaction on consumer behavioral intentions in service environments. Journal of Retailing, 76(2), 193-218.

Eid, Riyad. (2015). Integrating Muslim customer perceived value, satisfaction, loyalty and retention in the tourism industry: an empirical study. International Journal of Tourism Research, Int. J. Tourism Res., 17, 249-260.

Engel. (1995). Perilaku Konsumen. Jakarta: Bina Rupa Aksara.

Gusneli. (2016). Pengaruh Fasilitas Wisata Terhadap Kepuasan Pengunjung ke Objek Wisata Air Terjun Bayang Sani Kabupaten Pesisir Selatan. Jurnal Fakultas Pariwisata dan Perhotelan, Universitas Negeri Padang.

halim, roslilee ab. (2015). measurement of Shariah compliant hotel selection factors using importanceperformance analysis. Journal of Global Business and Social Entrepreneurship (GBSE), 1(2), 82-87.

Kamarudin, Lina Munirah Binti. (2012). Muslim tourists' typology in Malaysia: Perspectives and challenges. Proceedings of the Tourism and Hospitality International Conference (THIC 2012)

Ki Lee, Yong. (2008). Festivals capes and patrons' emotions, satisfaction, and loyalty. Journal of Business Research, 61, 56-64.

Kotler \& Keller. (2009). Manajemen Pemasaran. Bob Sabran (Translator). Jakarta: Penerbit Erlangga.

Nash, Robert. (2006). An investigation into customer satisfaction levels in the budget accommodation sector in Shotland. Tourism Management, 27, 525-532.

Odeny, Thomas A. (2013). Integration of HIV care with primary health care services: Effect on patient satisfaction and stigma in Rural Kenya". AIDS Research and Treatment, Article ID 485715.

Phillips, Woo Mi Jo. (2013). Tourist word of mouth and revisit intentions to rural tourism destinations: A Case of North Dakota, USA. International Journal of Tourism Research Int. J. Tourism Res., 15. 
Rahmatya. (2010). Analisis faktor - faktor yang mempengaruhi kepuasan sehingga tercipta word of mouth yang positif pada pelanggan Speedy di semarang. Jurnal Universitas Atma Jaya, Yogyakarta.

Rayo Vela, Marcelo. (2010). The influence of belonging to virtual brand communities on consumers' affective commitment, satisfaction and word-of-mouth advertising The ZARA case. Online Information Review, 35 (4), 517-542.

Timothy, Dallen J., \& Olsen, Daniel H. (2006). Tourism, Religion \& Spiritual Journeys. Great Britain: Routledge.

Umar. (2003). Riset Pemasaran dan Perilaku Konsumen. Jakarta: Gramedia Pustaka Utama.

Wan Ko, Don. (2002). A structural equation model of residents' attitudes for tourism development. Tourism Management, 23, 521-530.

Wardi, Y., Abror, A., \&Trinanda, O. (2018). Halal tourism: Antecedent of tourist's satisfaction and word of mouth (WOM). Asia Pacific Journal of Tourism Research, 23(5), 463-472. doi: 10.1080/10941665.2018.1466816

Wirandana. (2017). Pengaruh dimensi Islam dan religiusitas terhadap kepuasan konsumen sertadampaknyapada electronic word of mouth (Studi kasus Hotel Solo Syariah). Jurnal Universitas Pamulang.

Yeoh, Eugene. (2013). Understanding medical tourists: Word of mouth and viral marketing as potent marketing tools. Tourism Management, 34, 196-201.

Zailani, Suhaiza. (2016). Predicting Muslim medical tourists' satisfaction with Malaysian Islamic friendly hospitals. Tourism Management, 57, 159-167. 